\title{
PENGARUH KINERJA KEUANGAN DAERAH TERHADAP ALOKASI BELANJA MODAL DIBADAN PENGELOLAAN KEUANGAN DAERAH (BPKD) KABUPATEN/KOTA BULUKUMBA
}

\author{
Dewi Selviani Yulientinah, A. Masrura Nur \\ D4 Akuntansi Keuangan, Politeknik Pos Indonesia \\ dewiselviani@poltekpos.ac.id, Andimasruranur@gmail.com
}

\begin{abstract}
ABSTRAK
Pengukuran kinerja keuangan daerah dapat dilihat berdasarkan efektivitas, efisiensi, dan kemandirian keuangan daerah pada kementian/lembaga yang memerlukan agar dapat mengetahui pencapaian pengelolaan anggaran terhadap alokasi belanja modal. Penelitian ini dilatarbelakangi oleh maraknya fenomena mengenai pemasalahan bahwa belanja modal tumbuh lambat lima tahun terakhir, pemerintah diminta tambah pagu dan belanja modal pada keuangan kementrian/lembaga masih minim dikarenakan komposisi belanja masih didominasi oleh belanja operasional terutama belanja barang dan belanja pegawai. Penelitian ini bertujuan untuk mengetahui pengaruh kinerja keuangan daerah terhadap alokasi belanja modal. Dalam penelitian ini menggunakan metode kuantitatif. Adapun sampel yang digunakan adalah Laporan Realisasi Anggaran Pendapatan dan Belanja Daerah BPKD Kabupaten Bulukumba. Teknik Alat analisis data yang digunakan adalah uji normalitas data, analisis korelasi product moment, analisis regresi linear sederhana, analisis koefisien determinasi, dan uji t dengan menggunakan alat bantu SPSS versi 25.0. Hasil penelitian yang dilakukan dengan pengujian hipotesis menunjukkan secara parsial, kinerja keuangan daerah berpengaruh signifikan terhadap alokasi belanja modal.
\end{abstract}

Kata Kunci : Kinerja Keuangan Daerah, Alokasi Belanja Modal

\begin{abstract}
Measurement of regional financial performance can be seen based on the effectiveness, efficiency and independence of regional finances at ministries / institutions that need to know the achievement of budget management on capital expenditure allocations. This research is motivated by the widespread phenomenon regarding the problem that capital expenditure has grown slowly in the last five years, the government has been asked to increase the ceiling and capital expenditures on finance ministries / institutions are still minimal because the composition of expenditures is still dominated by operational spending, especially goods and personnel expenditures. This study aims to determine the effect of regional financial performance on the allocation of capital expenditures. In this study using quantitative methods. The sample used is the Report on the Realization of the Regional Budget of BPKD, Bulukumba Regency. The data analysis tools used are the data normality test, product moment correlation analysis, simple linear regression analysis, determination coefficient analysis, and test using the SPSS version of the tool. 25.0. The results of research conducted by testing the hypothesis show partially, regional financial performance has a significant effect on the allocation of capital expenditures.
\end{abstract}

Keywords: Regional Financial Performance, Capital Expenditure 


\section{PENDAHULUAN}

Perkembangan zaman di era globalisasi ini, aktivitas pembangunan pemerintahan di daerah tentu sulit dipisahkan dengan kebijakan pengelolaan keuangan daerah tersebut. Kewenangan fiskal yang besar di era desentralisasi sangat menentukan struktur dari anggaran yang disusun oleh pemerintah daerah (APBD). Alokasi belanja modal yang dimaksud merupakan alokasi pengeluaran untuk anggaran perolehan aset tetap dan/atau aset lainnya yang dimana memberi masa manfaat lebih dari satu periode akuntansi. Alokasi belanja modal diperlukan pengelolaan yang baik agar didapatkan hasil yang efektif serta efisien. Oleh karena itu diperlukan kinerja keuangan yang baik dalam kementerian atau lembaga itu sendiri agar dapat mengetahui sejauh mana keberhasilan telah dicapai atas pengelolaan alokasi belanja modal tersebut.

Adapun fenomena yang berkaitan berdasarkan beberapa analisis yang dilakukan terhadap realisasi pendapatan dan belanja negara yang ditemukan, seperti yang diterbitkan oleh kontan.co.id-jakarta pada 27 juni 2019 bahwa "Belanja modal tumbuh lambat lima tahun terakhir, pemerintah diminta tambah pagu". Seperti yang dijelaskan oleh Kementerian Keuangan melaporkan, realisasi belanja modal periode 2014-2019 kisaran rata-rata tumbuh $4,1 \%$ pertahunnya. Dengan membandingkan jenis belanja kementerian dan lembaga lainnya, pertumbuhan belanja modal merupakan belanja yang paling terendah dari belanja lainnya. Dalam artian bahwa anggaran belanja modal di tahun 2019 dipatok sebesar Rp 189,3 triliun. "Tragisnya belanja modal tumbuh 4,\%. Artinya, lebih besar belanja barang dibandingkan dengan belanja modal. kami berharap, belanja modal untuk tahun 2020 bisa naik sampai 10\% dengan menekan belanja barang,"(Sumber: https://nasional.kontan.co.id/news/belanja-modal-tumbuh-lambat-lima-tahun-terakhirpemerintah-diminta-tambah-pagu/). Selanjutnya adapun fenomena terkait penururan belanja modal yang telah diterbitkan katadata.co.id pada 19 november 2019 "Belanja modal baru capai setengah, penyaluran bansos hamper mentok", dimana kementrian keuangan telah mencatat hasil realisasi belanja modal sampai Oktober hanya mencapai 53\% dari pagu APBN. Realisasi belanja bantuan sosial tercatat paling tertinggi mencapai 94,53\% dari target, sedangkan belanja modal paling rendah sebesar 53,2\%. (Sumber : https://katadata.co.id/berita/2019/11/19/belanja-modal-baru-capai-setengah-penyaluranbansos-hampir-mentok/).

Hal ini menjelaskan bahwa belanja modal pada keuangan kementerian/lembaga masih minim dikarenakan adanya format belanja masih unggul oleh belanja operasional 
diantaranya belanja barang dan belanja pegawai. Adapun data mengenai Realisasi APBN Tahun Anggaran 2019 per 31 Maret 2020 adalah sebagai berikut :

Tabel 1 Realisasi Belanja APBN untuk periode berakhir 30 September 2019 (dalam triliun rupiah)

\begin{tabular}{|l|c|c|c|}
\hline \multicolumn{1}{|c|}{ Uraian } & APBN & Realisasi & $\begin{array}{c}\text { Presentase } \\
(\mathbf{\% )}\end{array}$ \\
\hline Belanja Pegawai & 381.3 & 291.8 & 76.5 \\
\hline Belanja Barang & 355.6 & 204.2 & 57.4 \\
\hline Belanja Modal & 179.3 & 80.4 & 44.8 \\
\hline Belanja Hibah & 1.9 & 0.2 & 9.4 \\
\hline Bantuan Sosial & 102.0 & 86.9 & 85.3 \\
\hline Belanja Lainnya & 114.0 & 2.0 & 1.8 \\
\hline
\end{tabular}

Sumber: Direktorat Jenderal Perbendaharaan

Berdasarkan tabel realisasi belanja APBN diatas dapat dilihat adanya belanja modal dalam laporan realisasi belanja APBN s/d 30 April 2019 yang dimana belanja pegawai, belanja barang, belanja hibah lebih meningkat dibandingkan dengan belanja modal. Dimana, lebih tinggi belanja pegawai, belanja barang dibandingkan dengan belanja modal. Kinerja keuangan merupakan "hasil atau prestasi yang telah dicapai oleh manajemen perusahaan dalam menjalankan fungsinya mengelola aset perusahaan secara efektif selama periode tertentu". Kinerja keuangan juga dapat diukur dengan menggunakan alat analisis yang berupa rasio. Rasio yang digunakan bertujuan untuk mengukur tingkat kemampuan daerah dalam membiayai kegiatan pemerintah yang diterima. Sama halnya dengan rasio yang digunakan pada perusahaan komersil, rasio keuangan pemerintah merupakan angkaangka dalam laporan keuangan pemerintah. Rasio yang digunakan dalam analisis kinerja keuangan pemerintah adalah rasio kemandirian keuangan daerah. Rasio kemandirian keuangan daerah ini dihitung dari laporan realisasi anggaran yang telah dibuat oleh pemerintah atas dasar transaksi yang telah dilaksanakan pada periode sebelumnya.

Dalam penelitian ini mengacu juga pada penelitian yang telah dilakukan peneliti sebelumnya mengenai Pengaruh Kinerja Keuangan Terhadap Alokasi Belanja Modal Pemerintah Daerah di Kabupaten dan Kota Provinsi Sumatera Barat Tahun 2013-2017 oleh Muhammad Arief \& Fefri Indra Arza, Pengaruh Kinerja Keuangan Daerah Terhadap Alokasi Belanja Modal di Provinsi Bali tahun 2018 oleh Ni Made Deni Indiyanti \& Henny Rahyuda, Pengaruh Kinerja Keuangan Daerah dan Budget Ratcheting Terhadap Alokasi Belanja Modal (Bukti empiris pada kabupaten/kota diprovinsi Aceh) tahun 2019 oleh Lilis Marlina, dan Pengaruh Kinerja Keuangan, Dana Alokasi Umum dan Silpa Pada Alokasi Belanja Modal tahun 2017 oleh Ade Imron Rosadi \& I D. G. Dharma Saputra. 
Berdasarkan uraian di atas, topik ini menarik untuk kemudian dijadikan sebagai bahan penelitiaan yaitu "Pengaruh Kinerja Keuangan Daerah Terhadap Alokasi Belanja Modal di Badan Pengelolaan Keuangan Daerah (BPKD) Kabupaten/Kota Bulukumba". Berikut adalah identifikasi masalah yang terdapat dalam penelitian ini adalah :

1. Bagaimana Kinerja Keuangan Daerah di Badan Pengelolaan Keuangan Daerah (BPKD) Kabupaten/Kota Bulukumba?

2. Bagaimana Alokasi Belanja Modal di Badan Pengelolaan Keuangan Daerah (BPKD) Kabupaten/Kota Bulukumba?

3. Bagaimana Pengaruh Kinerja Keuangan Daerah Terhadap Alokasi Belanja Modal di Badan Pengelolaan Keuangan Daerah (BPKD) Kabupaten/Kota Bulukumba?

\section{KAJIAN PUSTAKA}

Kinerja Keuangan

"Kinerja (performance) merupakan suatu gambaran mengenai tingkat pencapaian kegiatan/program/kebijakan dalam hal mewujudkan sasaran, tujuan, misi dan visi organisasi yang tertuang dalam strategic planning suatu organisasi tersebut." (Mahsun, 2016)

Kinerja Keuangan dalam organisasi sector public berkaitan dengan prestasi akuntabilitas organisasi dan manajemen dalam menghasilkan pelayanan public yang baik. Akuntabilitas yang merupakan ciri dari terapan good governance bukan hanya sekedar kemampuan bagaimana menunjukkan bahwa uang public tersebut telah dibelanjakan baik secara ekonomis, efektif, dan efisien. (Mardiasmo, 2018)

\section{Rasio Kemandirian Keuangan Daerah}

"Rasio kemandirian keuangan daerah tersebut dihitung dengan cara membandingkan jumlah penerimaan pendapatan asli daerah dibagi dengan jumlah pendapatan transfer dari pemerintah pusat dan provinsi serta pinjaman daerah. Semakin tinggi angka rasio ini menunjukan pemerintah daerah semakin tinggi kemandirian keuangan daerahnya.”(Kawatu, 2019).

Rasio kemandirian keuangan daerah juga menunjukkan ketergantungan suatu daerah terhadap pendapatan transfer (sumber data eksternal). Dalam hal ini diketahui bahwa semkain tinggi rasio kemandirian keuangan daerah maka tingkat ketergantukan disuatu 
daerah dengan pihak eksternal akan rendah begitupun. Rasio kemandirian keuangan daerah juga menunjukkan dengan adanya partisipasi masyarakat dalam pembangunan daerah.

\section{Alokasi Belanja Modal}

"Alokasi belanja modal merupakan anggaran yang digunakan dalam memperoleh aset tetap dan aset lainnya, yang memiliki masa manfaat dua belas bulan dalam satu periode akuntansi." maka diketahui bahwa unsur yang mempengaruhi alokasi belanja modal adalah realisasi belanja modal dan total realisasi belanja. Adapun realisasi belanja modal merupakan realisasi yang digunakan untuk perolehan memperoleh aset tetap dan aset lainnya, memiliki masa manfaat dua belas bulan. Sedangkan, total realisasi belanja merupakan keseluruhan realisasi belanja yang terdiri dari belanja pegawai, belanja barang dan belanja modal.

Berdasarkan kerangka pemikiran dan definisi operasional yang telah dibuat dan dipaparkan, maka hipotesis penelitian yang dapat diambil yaitu : “ Diduga terdapat signifikan Pengaruh Kinerja Keuangan Daerah terhadap Alokasi Belanja Modal pada Badan Pengelolaan Keuangan Daerah (BPKD) Kabupaten Bulukumba”.

\section{METODELOGI PENELITIAN}

\section{Jenis Penelitian}

Pada penelitian ini menggunakan metode kuantitatif. Adapun data yang diambil dan diperoleh nantinya berupa angka maka dari angka yang diperoleh selanjutnya akan dianalisis lebih lanjut dalam analisis data. Penelitian ini juga termasuk dalam penelitian asosiatif dengan bentuk hubungan kausal. "Assosiatif merupakan suatu rumusan masalah penelitian yang bersifat menanyakan hubungan antara dua variabel atau lebih". (Sugiyono, 2017a)

\section{Operasional Variabel}

Penelitian ini menggunakan dua (2) variabel yaitu variabel independen (X) dan variabel dependen $(\mathrm{Y})$ diantaranya:

1. Variabel Independen

$\mathrm{X}_{1}$ : Kinerja Keuangan daerah dengan pengukuran Rasio Kemandirian Keuangan Daerah

$$
R K K D=\frac{\mathrm{PAD}}{\text { Pendapatan }} \mathrm{X} 100 \% \quad\left\{\begin{array}{l}
\text { Gambar 1. Rumus Rasio Kemandirian } \\
\text { Keuangan Daerah }
\end{array}\right.
$$


2. Variabel Dependen

Y : Alokasi Belanja Modal

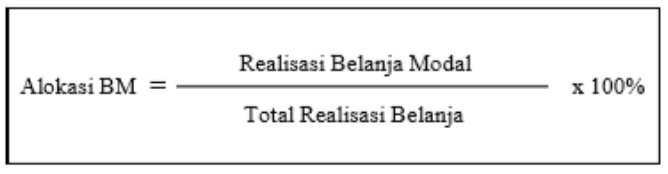

Gambar 2. Rumus Alokasi Belanja Modal

\section{Teknik Pengumpulan Data}

Adapun metode yang digunakan dalam pengumpulan data yang dimana data tersebut diperoleh dari Pengumpulan data dengan dokumen, dokumen merupakan catatan peristiwa yang sudah berlalu. Dokumen bisa berbentuk tulisan, gambar, atau karya-karya monumental dari seseorang (Sugiyono, 2017). Pengumpulan data dengan dokumen akan dikembangkan melalui data resmi dari Badan Pengelolaan Keuangan Daerah (BPKD) Kabupaten Bulukumba berupa laporan keuangan tahunan. Dan Library Research, data yang diperoleh untuk penelitian ini adalah data yang diperoleh dengan membaca literature, buku, artikel, jurnal dan hal lain yang berhubungan dengan aspek yang diteliti untuk memperoleh data yang valid dan akurat. Adapun literature yang dibaca dengan jurnal sebagai acuan mengenai kinerja keuangan dan alokasi belanja modal, dan beberapa buku yang menjelaskan teori mengenai alokasi belanja modal serta teori tentang metode penelitian.

\section{Teknik Sampling}

\section{Populasi}

"Populasi merupakan wilayah generalisasi yang terdiri atas: obyek/subyek yang memiliki kuantitas dan karakteristik tertentu yang ditetapkan oleh peneliti untuk dipelajari dan kemudian ditarik kesimpulannya" (Sugiyono, 2017). Maka dalam penelitian ini dapat menggunakan sampel yang diambil dari populasi itu sendiri. Maka, populasi yang terdapat dalam penelitian ini yaitu laporan keuangan Badan Pengelolaan Keuangan Daerah (BPKD) Kabupaten Bulukumba.

\section{Sampel}

"Sampel merupakan bagian dari jumlah serta karakteristik yang dimiliki oleh populasi tersebut". Pengambilan sampel yang digunakan dalam penelitian ini yaitu menggunakan Non Probality Sampling yakni Purposive Sampling. (Sugiyono, 2017). Dalam penelitian ini adapun sampel yang diteliti yaitu laporan keuangan Badan Pengelolaan Keuangan Daerah (BPKD) Kabupaten Bulukumba dengan mengambil laporan realisasi anggaran pendapatan dan belanja daerah (RAPBD) dan dimana datanya menggunakan data triwulan 
disetiap tahunnya dari tahun 2012-2019, untuk laporan keuangan 2020 sendiri belum dapat diakses public karena sedang dalam masa penyusunan oleh Badan Pengelolaan Keuangan Daerah (BPKD) Kabupaten Bulukumba itu sendiri dan belum diaudit.

\section{Teknik Analisis Data}

Dalam penelitian ini, menggunakan data sekunder untuk keseluruhan variabel, yaitu rasio kemandirian keuangan daerah dan alokasi belanja modal. Adapun tahapan analisis data pada penelitian ini menggunakan uji parsial (uji t), korelasi product moment, analisis regresi linear sederhana, dan analisis koefisien determinasi yang dimana setiap pengujiannya diuji dengan menggunakan alat bantu yaitu aplikasi SPSS versi 25.0 agar data yang dihasilkan lebih akurat.

\section{HASIL PENELITIAN DAN PEMBAHASAN}

\section{Analisis Data}

\section{Analisis Korelasi Product Moment}

Analisis product moment digunakan untuk mencari arah dan kuatnya hubungan antar variavel yaitu kinerja keuangan daerah yang diukur dengan rasio kemandirian keuangan daerah terhadap alokasi belanja modal secara parsial yang dinyatakan dengan koefisien korelasi (r). Maka dengan ini dilakukan pengelolaan data dengan menggunakan IBM SPSS Statistic 25.0, maka didapatka $\mathrm{n}$ hasil pengelolaan adalah sebagai berikut :

\section{Tabel 1}

\section{Korelasi Product Moment}

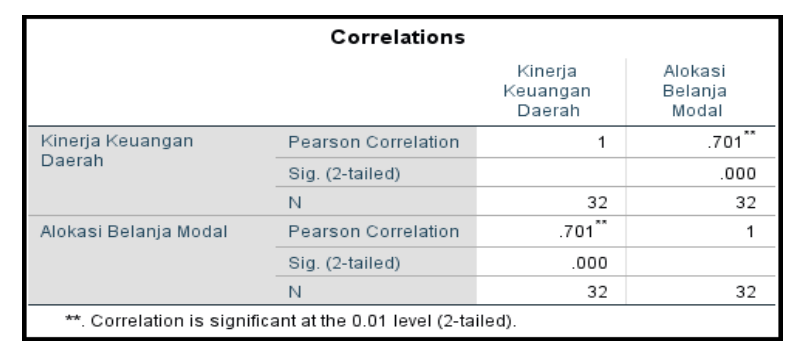

Sumber: IMB SPSS Statistic 25.0

Berdasarkan hasil pengelolaan data korelasi product moment menggunakan SPSS 25.0 dapat diketahui bahwa kinerja keuangan daerah yang diukur dengan menggunakan rasio kemandirian keuangan daerah berpengaruh positif terhadap alokasi belanja modal sebesar 0,701 dengan dan didaptakan nilai sig. $\quad(0,000<0,005)$ serta koefisien korelasi antara 
variabel kinerja keuangan daerah dan alokasi belanja modal sebesar $0,701>$ dari rtabel makakedua variabel tersebut dikategorikan dalam korelasi kuat.

\section{Regresi Linear Sederhana}

Untuk mengetahui bagaimana pengaruh kinerja keuangan daerah terhadap alokasi belanja modal, maka perlu dilakukan perhitungan dengan menggunakan rumus regresi. Analisis regresi linear digunakan untuk mengukur pengaruh dari variabel independen terhadap variabel dependen. Adapun jenis regresi yang dipakai adalah regresi linear sederhana yang dimana digunakan apabila diketahui satu variabel independen dan satu variabel dependen.

Dalam menentukan regresi linear sederhana, adapun pengolahan data yang dilakukan dengan IMB SPSS Statistic 25.0 berikut adalah hasil dari regresi linear sederhana :

Tabel 2

\section{Regresi Linear Sederhana}

\begin{tabular}{|c|c|c|c|c|c|c|}
\hline \multicolumn{7}{|c|}{ Coefficients $^{\mathrm{a}}$} \\
\hline \multirow[b]{2}{*}{ Model } & & \multicolumn{2}{|c|}{ Unstandardized Coefficients } & \multirow{2}{*}{$\begin{array}{c}\text { Standardized } \\
\text { Coefficients } \\
\text { Beta }\end{array}$} & \multirow[b]{2}{*}{$t$} & \multirow[b]{2}{*}{ Sig. } \\
\hline & & B & Std. Error & & & \\
\hline 1 & (Constant) & 9.042 & 1.344 & & 6.728 & .000 \\
\hline & $\begin{array}{l}\text { Kinerja Keuangan } \\
\text { Daerah }\end{array}$ & .435 & .081 & .701 & 5.386 & .000 \\
\hline
\end{tabular}

Sumber: IMB SPSS Statistic 25.0

Berdasarkan hasil pengolahan data menggunakan IMB SPSS 25.0, maka didapatkan persamaan regresi linear sederhana adalah

$$
\begin{gathered}
\mathbf{Y}=\mathbf{a}+\mathbf{b X} \\
\mathrm{Y}=9.045+0.435 \mathrm{X}
\end{gathered}
$$

Dimana:

$$
\begin{array}{ll}
\mathrm{X} & =\text { Kinerja Keuangan Daerah } \\
\mathrm{Y} & =\text { Alokasi Belanja Modal } \\
\mathrm{b} & =\text { Koefisien Regresi }
\end{array}
$$

Maka dapat diambil kesimpulan berdasarkan persamaan regresi linear sederhana bahwa koefisien regresi variabel kinerja keuangan daerah (X) sebesar 0.435 dapat diartikan jika variabel independen lain nilainya tetap dan nilai variabel kinerja keuangan mengalami kenaikan 1, maka alokasi belanja modal akan mengalami kenaikan sebesar 0.435 . karena koefisisen bernilai positif maka terjadi hubungan positif antara kinerja keuangan daerah (X) terhadap alokasi belanja modal (Y) sehingga kenaikan dari kinerja keuangan daerah (X) mengakibatkan kenaikan pada alokasi belanja modal (Y). 


\section{Analisis Koefisien Determinasi}

Koefisien determinasi digunakan untuk mengetahui besarnya pengaruh variabel independen (Kinerja Keuangan Daerah (X)) terhadap variabel dependen (Alokasi belanja modal (Y)). Dengan menggunakan IMB SPSS Statistic 25.0 diperoleh hasil analisis koefisien determinasi sebagai berikut :

Tabel 3

Analisis Koefisisen Determinasi

\begin{tabular}{|c|c|c|c|c|}
\hline \multicolumn{5}{|c|}{ Model Summary } \\
\hline Model & $\mathrm{R}$ & R Square & $\begin{array}{c}\text { Adjusted R } \\
\text { Square }\end{array}$ & $\begin{array}{l}\text { Std. Error of } \\
\text { the Estimate }\end{array}$ \\
\hline 1 & $.701^{a}$ & .492 & .475 & 5.545 \\
\hline
\end{tabular}

Sumber: IMB SPSS Statistic 25.0

Berdasarkan tabel 4.6 diatas, maka diketahui bahwa nilai $R$ Square $\left(\mathrm{r}^{2}\right)$ adalah sebesar 0.492 yang dimana besaran pengaruh variabel independen (Kinerja Keuangan Daerah) terhadap variabel dependen (Alokasi Belanja Modal) dihitung melalui persamaan koefisien determinasi sebagai berikut:

$$
\begin{aligned}
& \mathbf{K d}=\mathbf{r}^{2} \times \mathbf{1 0 0 \%} \\
& \mathrm{Kd}=0.701^{2} \times 100 \% \\
& \mathrm{Kd}=49.2 \%
\end{aligned}
$$

Besaran koefisien determinasi yang diperoleh sebesar $49.2 \%$, berarti variabel kinerja keuangan daerah berpengaruh sebanyak 49.2\% terhadap alokasi belanja modal. Sisanya, sebanyak 50.8\% dipengaruhi variabel lain yang yang tidak diteliti dalam penelitian ini.

\section{Uji Parsial (Uji t)}

Pengujian hipotesis dalam penelitian ini dengan menggunakan uji-t untuk menunjukkan seberapa besar pengaruh satu variabel independen secara individual dalam menerangkan variasi-variasi variabel dependen. Dalam penelitian ini menggunakan uji dua pihak (two tails test). Dimana syarat penerimaan hipotesis menggunakan uji-t adalah:

1. Ho ditolak, Ha diterima : apabila $t_{\text {hitung }}>\mathrm{t}_{\text {tabel }}$ atau $-\mathrm{t}_{\text {hitung }}<-\mathrm{t}_{\text {tabel }}$ dengan tingkat signifikansi $\alpha(<0.05)$

2. Ho diterima, Ha ditolak : apabila $\mathrm{t}_{\text {hitung }}<\mathrm{t}_{\text {tabel }}$ atau $-\mathrm{t}_{\text {hitung }}>-\mathrm{t}_{\text {tabel }}$ dengan tingkat signifikansi $\alpha(<0.05)$ 
Hasil pengujian secara pasial dengan uji-t menggunakan aplikasi SPSS Statistic 25.0 dapat dilihat pada tabel berikut:

Tabel 4

\section{Uji Parsial (Uji t)}

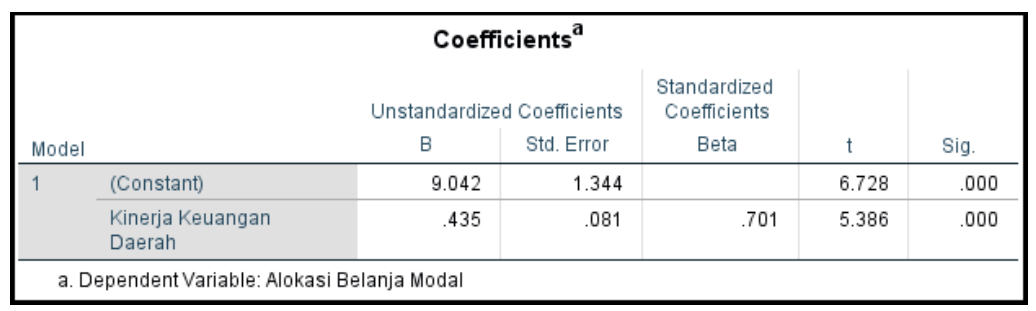

Sumber: IMB SPSS Statistic 25.0

Hasil uji t dengan menggunakan SPSS Statistic 25.0 dalam tabel diatas antara variabel kinerja keuangan daerah terhadap alokasi belanja modal yang dapat dilihat dari kolom $\mathrm{t}$ dalam coefficient menunjukkan bahwa nilai $t_{\text {hitung }}$ sebesar 5.386. Dengan melihat pada $\mathrm{t}_{\text {tabel }}$ jumlah data $\mathrm{n}=32$ dan $(\mathrm{df})=\mathrm{n}-\mathrm{k}-1$ atau 32-1-1 $=30$ pada tingkat kesalahan $\alpha=0.05$ dengan pengujian dua pihak maka diperoleh $t_{\text {tabel }}$ sebesar 2.042. Dalam hal ini menunjukkan bahwa $t_{\text {hitung }}>t_{\text {tabel }}$ dimana Ho ditolak dan Ha diterima. Artinya kinerja keuangan daerah secara parsial terdapat pengaruh yang signifikan terhadap alokasi belanja modal.

\section{Pembahasan Hasil Penelitian}

Kinerja Keuangan Daerah di Badan Pengelolaan Keuangan Daerah (BPKD)

\section{Kabupaten/Kota Bulukumba}

Berdasarkan hasil pengujian yang dilakukan, maka diperoleh bahwa kinerja keuangan daerah yang diukur menggunakan rasio kemandirian keuangan daerah dalam pengukuran rasio kemandirian keuangan daerah (RKKD) digunakan untuk menunjukkan tingkat kemampuan suatu daerah dalam membiayai kegiatan pemerintahnya sendiri dimana pembangunan serta pelayanan kepada masyarakat yang sudah membayar pajak dan retribusi sebagai sumber pendapatan yang diperlukan daerah. Adapun tingkat rasio kemandirian keuangan daerah terendah terjadi pada triwulan keempat pada tahun 2014 yaitu sebesar 3.39\%. Sedangkan untuk tingkat rasio kemandirian keuangan daerah tertinggi terjadi pada tahun 2018 di triwulan ketiga yaitu sebesar 43.91\%. Melalui perhitungan rasio kemandirian menunjukkan bahwa rasio kemandirian keuangan daerah di BPKD Kabupaten/Kota Bulukumba pada tahun 2018 rasio kemandirian ini merupakan yang tertinggi dari tahun lainnya yang berarti menunjukkan tingkat ketergantungan daerah 
terhadap bantuan pemerintah pusat semakin rendah, sehingga perlu meningkatkan pasrtisipasi masyarakat dalam membayar pajak dan retribusi daerah.

Analisis regresi linear sederhana menunjukkan bahwa perolehan nilai konstanta (a) sebesar 9.042 dan nilai koefisien regresi (b) sebesar 0.435 dapar diartikan bahwa, jika nilai variabel kinerja keuangan daerah (X) mengalami kenaikan 1, maka alokasi belanja modal (Y) akan mengalami peningkatan sebesar 0.435 .

Penelitian ini juga mendukung teori dari (Mardiasmo, 2018) "Kinerja Keuangan dalam organisasi sector public berkaitan dengan prestasi dan akuntabilitas organisasi dan manajemen dalam menghasilkan pelayanan public yang lebih baik." Melihat hasil dari pengujian hipotesis untuk variabel (X) kinerja keuangan daerah memiliki pengaruh signifikan terhadap alokasi belanja modal sebagai variabel (Y).

\section{Alokasi Belanja Modal di Badan Pengelolaan Keuangan Daerah (BPKD) Kabupaten/Kota Bulukumba}

Alokasi belanja modal merupakan anggaran yang digunakan untuk memperoleh aset tetap dan aset lainnya yang dinyatakan dalam persentase, yang memiliki masa manfaat dua belas bulan. Alokasi belanja modal menunjukkan seberapa besar anggaran yang dialokasikan untuk kepentingan belanja modal.

Berdasarkan hasil pengujian yang dilakukan, maka diperoleh bahwa alokasi belanja modal tertinggi terjadi pada tahun 2018 di triwulan pertama yaitu 29.67\%. Hal ini menunjukkan bahwa alokasi belanja modal yang dialokasikan untuk belanja modal di BPKD Kabupaten/Kota Bulukumba sebesar 29.67\% dari total belanja. Sedangkan alokasi belanja modal terendah terjadi pada tahun 2015 dari triwulan ketiga yaitu yang hanya sebesar 3.80\% dari total belanja. Hal ini menunjukkan bahwa alokasi belanja modal di BPKD Kabupaten/Kota Bulukumba masih rendah dan masih banyak didominasi oleh belanja pegawai dan belanja barang. Dari hasil analisis regresi linear sederhana menunjukkan bahwa perolehan nilai konstanta (a) sebesar 9.042 dan nilai koefisien regresi (b) sebesar 0.435 dapar diartikan bahwa, jika nilai variabel kinerja keuangan daerah (X) mengalami kenaikan 1, maka alokasi belanja modal (Y) akan mengalami peningkatan sebesar 0.435. keuangan daerah pada BPKD Kabupaten/Kota Bulukumba sudah baik.

Penelitian ini juga mendukung teori dari penelitian terdahulu dari (Indiyanti \& Rahyuda, 2018) dimana “Alokasi belanja modal merupakan anggaran yang digunakan untuk memperoleh aset tetap dan aset lainnya, yang memiliki masa manfaat dua belas bulan.” 


\section{Pengaruh Kinerja Keuangan Daerah Terhadap Alokasi Belanja Modal di Badan Pengelolaan Keuangan Daerah di Badan Pengelolaan Keuangan Daerah (BPKD) \\ Kabupaten/Kota Bulukumba}

Dalam penelitian ini dimana menggunakan pengukuran kinerja keuangan menggunakan tolak ukur rasio kemandirian keuangan daerah yang berbeda untuk menilai pengaruh kinerja keuangan daerah sebagai variabel independen (X) terhadap alokasi belanja modal sebagai variabel dependen (Y) dengan objek penelitian adalah kantor Badan Pengelolaan Keuangan Daerah (BPKD) Kabupaten/Kota Bulukumba. Penelitian ini menggunakan data sekunder berdasarkan laporan realisasi anggaran satuan kerja dimulai dari periode 2012 sampai dengan periode 2019 yang dimana laporan realisasi anggaran data yang dipakai per triwulan dalam setiap tahunnya.

Berdasarkan uji statistic yang dilakukan yaitu analisis koefisien product moment yang dinyatakan dengan koefisien korelasi (r), adapun besarnya koefisien korelasi antara kinerja keuangan daerah dengan alokasi belanja modal berdasarkan perhitungan yaitu sebesar 0.071 yang berada pada interval $0.600-0.799$. Hal tersebut menunjukkan adanya pengaruh positif antara kinerja keuangan daerah terhadap alokasi belanja modal yang termasuk dalam kategori kuat. Sehingga kinerja keuangan daerah mempengaruhi alokasi belanja modal secara positif dimana hal tersebut menunjukkan bahwa pengukuran kinerja dengan rasio kemandirian keuangan daerah maka akan menyebabkan peningkatan terhadap alokasi belanja modal.

Adapun hasil uji t secara parsial, kinerja keuangan daerah mempunyai $t_{\text {hitung }}$ sebesar 5.386 dan $t_{\text {tabel }}$ sebesar 2.042 hal ini menunjukkan bahwa $t_{\text {hitung }}>t_{\text {tabel }}$ maka Ho ditolak dan Ha diterima, berarti secara parsial terdapat pengaruh signifikan antara variabel kinerja keuangan daerah terhadap alokasi belanja modal. Berdasarkan hasil uji analisis korelasi regresi linear sederhana didapatkan persamaan linear $\mathrm{Y}=9.045+0.435 \mathrm{X}$ dan koefisien determinasi yang diperoleh nilai $\mathrm{r}^{2}$ sebesar $49.2 \%$ yang berarti kinerja keuangan berpengaruh sebesar $49.2 \%$ terhadap alokasi belanja modal dan $50.8 \%$ lainnya dipengaruhi oleh factor lain diluar penelitian ini.

Hasil penelitian ini juga didukung dengan teori dari penelitian terdahulu (Umar \& Marlina, 2016) dimana dalam penelitian ini kinerja keuangan daerah yang diukur menggunakan rasio kemandirian keuangan daerah memiliki pengaruh secara parsial terhadap alokasi belanja modal dengan penelitian Lilis Marlina (2019) tentang Pengaruh Kinerja Keuangan Daerah dan Budget Ratcheting terhadap Alokasi Belanja Modal (bukti empiris pada Kabupaten/Kota di Provinsi Aceh. 


\section{KESIMPULAN DAN SARAN}

Berdasarkan identifikasi masalah, hipotesis dan hasil pengujian yang telah dilakukan untuk mengetahui pengaruh Kinerja Keuangan Daerah berdasarkan rasio kemandirian keuangan daerah (X) terhadap Alokasi Belanja Modal (Y) maka dapat disimpulkan sebagai berikut :

1. Berdasarkan hasil penelitian menunjukkan bahwa kinerja keuangan daerah yang diukur menggunakan rasio kemandirian keuangan daerah pada kantor Badan Pengelolaan Keuangan Daerah (BPKD) Kabupaten/Kota Bulukumba yang dimana dapat dilihat dari tingkat rasio kemandirian keuangan daerah terendah terjadi pada triwulan keempat pada tahun 2014 dan untuk tingkat rasio kemandirian keuangan daerah tertinggi terjadi pada tahun 2018 di triwulan ketiga sehingga pada tahun 2018 rasio kemandirian ini merupakan yang tertinggi dari tahun lainnya yang berarti menunjukkan tingkat ketergantungan daerah terhadap bantuan pemerintah pusat semakin rendah, sehingga perlu meningkatkan pasrtisipasi masyarakat dalam membayar pajak dan retribusi daerah.

2. Berdasarkan hasil penelitian menunjukkan bahwa alokasi belanja modal pada kantor Badan Pengelolaan Keuangan Daerah (BPKD) Kabupaten/Kota Bulukumba maka diperoleh bahwa alokasi belanja modal tertinggi terjadi pada tahun 2018 di triwulan pertama dan alokasi belanja modal terendah terjadi pada tahun 2015 dari triwulan ketiga total belanja. Hal ini menunjukkan bahwa alokasi belanja mdal di BPKD Kabupaten/Kota Bulukumba masih rendah dan masih banyak didominasi oleh belanja pegawai dan belanja barang.

3. Berdasarkan hasil pengolahan data dengan menggunakan program IMB SPSS Statistic 25.0 dari pengujian hipotesis secara simultan dapat disimpulkan bahwa kinerja keuangan daerah $(\mathrm{X})$ berpengaruh signifikan terhadap alokasi belanja modal $(\mathrm{Y}) \mathrm{di}$ Kantor Badan Pengelolaan Keuangan Daerah (BPKD) Kabupaten/Kota Bulukumba yaitu sebesar $49.2 \%$ dan sisanya sebesar $50.8 \%$ yang dipengaruhi oleh factor lain.

Adapun saran untuk peneliti selanjutnya melakukan penelitian ini adalah sebagai berikut: 
1. Peneliti selanjutnya diharapkan untuk mengkaji lebih banyak sumber maupun referensi yang terkait dengan kinerja keuangan daerah dan alokasi belanja modal agar hasil penelitiannya dapat lebih lengkap lagi.

2. Bagi pihak-pihak lain yang ingin meneliti topik ini secara lebih dalam, penelitian ini dapat dikembangkan dengan memilih jenis perusahaan yang berbeda dan menambah atau mengembangkan variabel dependen lainnya yang mempengaruhi alokasi belanja modal.

\section{DAFTAR PUSTAKA}

Badan Pengelola Keuangan Daerah (BPKD). Website Resmi, (Online) https://bulukumbakab.go.id/

Kontan.co.id. Website Resmi Kontan, (Online) (https://www.kontan.co.id/, diakses 20 April 2019)

Katadata.co.id. Website Resmi Kata Data, (Online)

(https ://katadata.co.id/berita/2019/11/19/belanja-modal-baru-capai-setengahpenyaluran-bansos-hampir-mentok)

Indiyanti, N. M. D., \& Rahyuda, H. (2018). Pengaruh Kinerja Keuangan Daerah Terhadap Alokasi Belanja Modal di Provinsi Bali. E-Jurnal Manajemen Universitas Udayana, 7(9), 4713. https://doi.org/10.24843/ejmunud.2018.v07.i09.p04

Kawatu, F. S. (2019). Analisis Laporan Keuangan Sektor Publik. Penerbit Buku Pendidikan Deepublish.

Mahsun, M. (2016). Pengukuran Kinerja Sektor Publik (Edisi Pert). BPFE Yogyakarta.

Mardiasmo. (2017). Akuntansi Sektor Publik.

Mardiasmo. (2018). Akuntansi Sektor Publik.

Rahayu, S., Junaidi, \& Hariri. (2020). Pengaruh Kinerja Keuangan terhadap Return Saham (studi empiris pada perusahaan Manufaktur yang terdaftar di BEI tahun 2016-2018). E-JRA Universitas Islam Malang, 09(04), 25-36.

Sugiyono. (2017a). Metode Penelitian Kuantitatif, Kualitatif, Dan R\&D. Alfabeta.

Sugiyono. (2017b). Statistika Untuk Penelitian. Alfabeta.

Wiratna, S. (2016). KUPAS TUNTAS PENELITIAN AKUNTANSI DENGAN SPSS (Mona (ed.)). Pustaka Baru Press. 